\title{
Tall Waterhemp (Amaranthus tuberculatus) and Palmer amaranth (Amaranthus palmeri) Seed Production and Retention at Soybean Maturity
}

\author{
Lauren M. Schwartz, Jason K. Norsworthy, Bryan G. Young, Kevin W. Bradley, Greg R. Kruger, \\ Vince M. Davis, Larry E. Steckel, and Michael J. Walsh*
}

Two of the most problematic Amaranthus species in soybean production today are tall waterhemp and Palmer amaranth. This study determined the percentage of tall waterhemp and Palmer amaranth seed that was retained by the weed at soybean maturity to assess the likelihood of using at-harvest weed seed control tactics for soil seedbank management. Palmer amaranth plants were collected from fields in Arkansas, Tennessee, Illinois, Missouri, and Nebraska, and tall waterhemp plants were collected from fields in Nebraska, Missouri, Wisconsin, and Illinois. Collected plants were assessed for at-harvest weed seed retention in 2013 and 2014. Within 1 wk of soybean maturity, Amaranthus plants were harvested and the loose soil and debris beneath the plants were swept into a pan with a hand broom to collect any shattered seed. Percent seed retention ranged from 95 to $100 \%$ for all states both years, regardless of species. There was a strong correlation between weed biomass $(\mathrm{g})$ and total seed production (no. plant ${ }^{-1}$ ) in that the larger the plant, the more seeds it produced. However, there was no correlation between percent seed retention and weed biomass, which indicates that regardless of plant size and likely time of emergence, seed retention is high at the time of crop maturity. Overall, this study demonstrated that there is great opportunity for Palmer amaranth and tall waterhemp seed capture or destruction at soybean harvest. It is likely that nearly all of the seeds produced for both Amaranthus species passes through the combine during harvest to be returned to the soil seedbank. Thus, there is continued need for research focused on developing and testing harvest weed seed control tactics that aim at reducing the soil seedbank and lowering risks for evolution of herbicide resistance.

Nomenclature: Palmer amaranth, Amaranthus palmeri S. Wats.; tall waterhemp, Amaranthus tuberculatus (Moq.) Sauer; soybean, Glycine max (L.) Merr.

Keywords: Amaranthus, harvest weed seed control, soil seedbank, weed biology, weed ecology.

Dos de las especies de Amaranthus más problemáticas en la producción de soja, hoy en día, son Amaranthus tuberculatus y
Amaranthus palmeri. Este estudio determinó el porcentaje de semilla de A. tuberculatus y A. palmeri que fue retenido por la
maleza al momento de la madurez de la soja, para evaluar la probabilidad de usar tácticas para el control de semilla de
malezas durante la cosecha para el manejo del banco de semillas. Plantas de A. palmeri fueron colectadas en campos en
Arkansas, Tennessee, Illinois, Missouri, y Nebraska, y plantas de A. tuberculatus fueron colectadas en campos en Nebraska,
Missouri, Wisconsin, e Illinois. Las plantas colectadas fueron evaluadas por su retención de semilla al momento de la
cosecha en 2013 y 2014 . A la semana de la madurez de la soja, las plantas de Amaranthus fueron cosechadas y el suelo
suelto y los residuos vegetales debajo de las plantas fueron removidos con una escoba de mano y fueron depositados en un
contenedor para colectar semilla que hubiera caído al suelo antes de la cosecha. El porcentaje de retención de semilla varió
de 95 a $100 \%$ en todos los estados y en ambos años, sin importar la especie. Hubo una correlación alta entre la biomasa de
la maleza (g) y el total de semilla producida (no. planta ${ }^{-1}$ ), así entre más grande la planta, más semilla produjo. Sin
embargo, no hubo una correlación entre el porcentaje de retención de semilla y la biomasa de la maleza, lo que indica que
sin importar el tamaño de la planta y el momento de emergencia, la retención de la semilla es alta al momento de la
madurez del cultivo. En general, este estudio demostró que existe una gran oportunidad para capturar o destruir la semilla
de A. palmeri y A. tuberculatus durante la cosecha de la soja. Es probable que casi toda la semilla producida por ambas

DOI: 10.1614/WT-D-15-00130.1

* First and second authors: Postdoctoral Research Associate (ORCID: 0000-0001-8305-4319) and Professor, Department of Crop, Soil, and Environmental Sciences, University of Arkansas, Fayetteville, AR 72704; third author: Associate Professor, Department of Botany and Plant Pathology, Purdue University, West Lafayette, IN 47907; fourth author: Associate Professor, Department of Plant Sciences, University of Missouri, Columbia, MO 65211; fifth author: Assistant Professor and Extension Specialist, University of Nebraska, North Platte, NE 69101; sixth author: Assistant Professor, Department of Agronomy, University of Wisconsin, Madison, WI 53706; seventh author: Associate Professor, Department of Plant Sciences, University of Tennessee, Jackson, TN 38301; eighth author: Senior Research Fellow, School of Plant Biology, University of Western Australia, Crawley WA, Australia 6009. Corresponding author's E-mail: lmschwar@uark.edu 
especies de Amaranthus pase por la cosechadora al momento de la cosecha y que sea retornada al banco de semillas del suelo. Por esta razón, existe una necesidad de investigación que se enfoque en el desarrollo y evaluación de tácticas de control de semillas de malezas durante la cosecha con el objetivo de reducir el banco de semillas del suelo y a su vez disminuir el riesgo de evolución de resistencia a herbicidas.

The Amaranthus species are among the most troublesome weeds in row-crop production. Specifically, tall waterhemp and Palmer amaranth are the most problematic Amaranthus species in the United States (Johnson 2000; Norsworthy et al. 2014). These dioecious, summer annual forbs have many characteristics that make them ideal agricultural weeds, such as environmental adaptability, discontinuous emergence pattern, rapid growth, and evolved resistance to multiple herbicide modes of action (Heap 2014; Horak and Loughin 2000; Sellers et al. 2003). These two Amaranthus species, through morphological and physiological means, are an increasing threat to agricultural systems across the Midwest and southern United States (Johnson 2000; Norsworthy et al. 2014).

Weeds and crops interact primarily by competing for shared resources such as light, nutrients, water, and space. The competition effect is further driven by ecological factors such as weed emergence relative to the crop (Dieleman et al. 1996; Knezevic et al. 1994), the effects of weed density (Dunan et al. 1995), the duration of competition (Swanton et al. 2015), and the morphology and life history of the weed species (Davis et al. 2015). For example, Palmer amaranth and tall waterhemp have the ability to grow 2 to $3 \mathrm{~m}$ tall (Horak and Loughin 2000; Trucco and Tranel 2011) and have an extended period of seedling emergence, which can continue late into the row-crop growing season (Hartzler et al. 1999). A density of only 8 Palmer amaranth plants $\mathrm{m}^{-2}$, present at soybean emergence, reduced soybean grain yield by $78 \%$ compared with $56 \%$ yield loss in soybeans competing with same density of tall waterhemp plants established at crop emergence (Bensch et al. 2003). Tall waterhemp reduced soybean yields by as much as $56 \%$ when it emerged with the crop, and 10\% when it emerged as late as the V4 soybean stage (Steckel and Sprague 2004a; Steckel et al. 2004, 2008).

Weed-crop competition is not limited to only one growing season. The high fecundity and seed dormancy of Palmer amaranth and tall waterhemp ensure carryover to subsequent year(s). For example, without competition, tall waterhemp and Palmer amaranth can produce up to 1 million seeds per plant (Keeley et al. 1987; Nordby et al. 2007), whereas when in competition with soybean, the Amaranthus species can produce up to 500,000 seeds per plant (Sellers et al. 2003; Ward et al. 2013). Amaranthus species seed are predominantly gravity-dispersed, but can also be spread by water, birds or animals, and through agricultural management practices such as plowing, mowing, harvesting, and spreading compost (Costea et al. 2005; Norsworthy et al. 2009; Ward et al. 2013). Although these seeds lack specialized dispersal mechanisms, strong winds can move seeds over $300 \mathrm{~m}$ and the pollen over $500 \mathrm{~m}$ (Norsworthy et al. 2012; Sosnoskie et al. 2012).

Today, many of the Amaranthus species have evolved resistance to multiple herbicide modes of action (Heap 2014; Zimdahl 2004), and the concurrent maturation of crops and annual weed species has resulted in the unintentional "harvesting" of the weed seeds when commercial harvesting occurs (Walsh et al. 2013). Furthermore, the weed seeds can be redistributed on the soil surface, causing further spread, as well as increasing the soil seedbank (Walsh and Powles 2014). Thus, alternative nonchemical weed control practices are needed to control the herbicide-resistant or escaped weeds (Walsh et al. 2013). Harvest weed seed control (HWSC) tactics have been developed that include various cultural and mechanical management practices to decrease the number of weed seeds replenishing the soil seedbank. These management practices include the use of chaff carts (Walsh et al. 2012), narrow-windrow burning (Walsh and Newman 2007), the Harrington Seed Destructor (Walsh et al. 2012), bale-direct systems (Walsh and Powles 2007), and other means of targeting the chaff during harvest (Gill 1996; Walsh and Powles 2007).

There are many challenges associated with preventing inputs to the soil seedbank, but the biggest is preventing seed return over a large area and having a diverse weed seedbank (Norsworthy et al. 2012; Swanton and Weise 1991). The length of 
time that seeds remains viable in the soil seedbank determines how long best management practices (BMP) must be used to reduce the seedbank and any herbicide-resistant seed (Norsworthy et al. 2012). Seed retention levels for Palmer amaranth and tall waterhemp in soybean fields across the United States have not been investigated and therefore, the potential efficacy of HWSC systems on these species remains unknown. Thus, the objective of this study was to determine the percentage of total tall waterhemp and Palmer amaranth seed production that was retained on the plant at soybean maturity, and therefore assess the likelihood of using HWSC tactics for soil seedbank management.

\section{Materials and Methods}

Data Collection. In 2013 and 2014, Palmer amaranth plants were collected from fields in Arkansas, Tennessee, Illinois, Missouri, and Nebraska, and tall waterhemp plants were collected from Nebraska, Missouri, Wisconsin, and Illinois. Additionally, Palmer amaranth was collected in Arkansas in 2012 to act as a preliminary study (data not shown). In each state, five separate commercial soybean fields with tall waterhemp and an additional five separate fields with Palmer amaranth were chosen. Field histories were not possible to collect due to the random sampling across the states. Five seed-producing Amaranthus plants were collected at soybean maturity from each field for a total of 25 plants per species per state. Soybean maturity was similar across fields within a state. The date of collection was recorded and the number of days until or following soybean maturity $( \pm 7 \mathrm{~d})$ was visually estimated. Plants were selected from fields that had a low density of Amaranthus plants $(<5$ plants $\mathrm{m}^{-2}$ ) because seed loss from shattering was determined by sweeping up all of the seed on the soil surface beneath individual Amaranthus plants. It was unknown if the collected plants were herbicideresistant or from a late-emerging flush. A hand broom was used to sweep the seed, loose debris, and loose soil into a dustpan, which was then transferred into a bag for further analysis. In addition, each Amaranthus plant was clipped at the soil surface and bagged to obtain aboveground dry weights (the entire plant was oven dried for $72 \mathrm{~h}$ at $55 \mathrm{C}$ ). Plants were then threshed and $0.5 \mathrm{~g}$ of seed from the seedhead were counted and weighed, and used to determine the total number of seeds on the plant.

The bagged seed and soil mixtures were thoroughly mixed in 36 by 48 by $5 \mathrm{~cm}$ trays at an approximate $1: 1$ ratio $(\mathrm{v} / \mathrm{v})$ of commercial potting mix and sample retrieved from the soil surface beneath each plant. These samples were placed into a greenhouse in early January each year at the University of Arkansas to evaluate seedling emergence over two separate 1-mo periods. Emerged seedlings were counted and removed after 1 mo, and then samples were placed outside for a further month-long cold stratification period, followed by a return of the samples to the greenhouse to monitor emergence for an additional month. There were few plants emerging by the end of evaluation, but it is possible that some viable seed might have remained dormant. Hence, the exhaustive germination technique only allowed for an estimate of the seed that had shattered prior to soybean maturity. The number of germinated seedlings were summed and used to determine the fraction of seed that shattered prior to soybean maturity. Percent seed retention was then determined by the following equation:

$$
\begin{aligned}
\% \text { seed retention }= & \text { total no. of seed } \\
& \quad /(\text { total no. of seed } \\
& \quad+\text { germinated seed in soil })) \\
& * 100
\end{aligned}
$$

Statistical Analyses. Data (biomass in g), estimated total number of seeds plant ${ }^{-1}$, seedling emergence, and percent seed retention) were analyzed with a three-way ANOVA using the PROC MIXED procedure in SAS 9.3 (SAS Institute Inc., Cary, NC). Species, year, and state were the fixed effects, and site location was a random effect in the model. Significance was assessed at $\mathrm{P}<0.05$. A first-order autoregressive covariance structure (type $=\operatorname{ar}(1)$ in PROC MIXED) was used in the model because it returned the lowest Akaike's Information Criteria (AIC) fit statistic compared with unstructured or compound symmetry. Means separation of significant interactions and, when appropriate, main effects, were based on least square means (LSMeans) tests. To determine the effects of state and species on percent seed retention, a correlation analysis was 


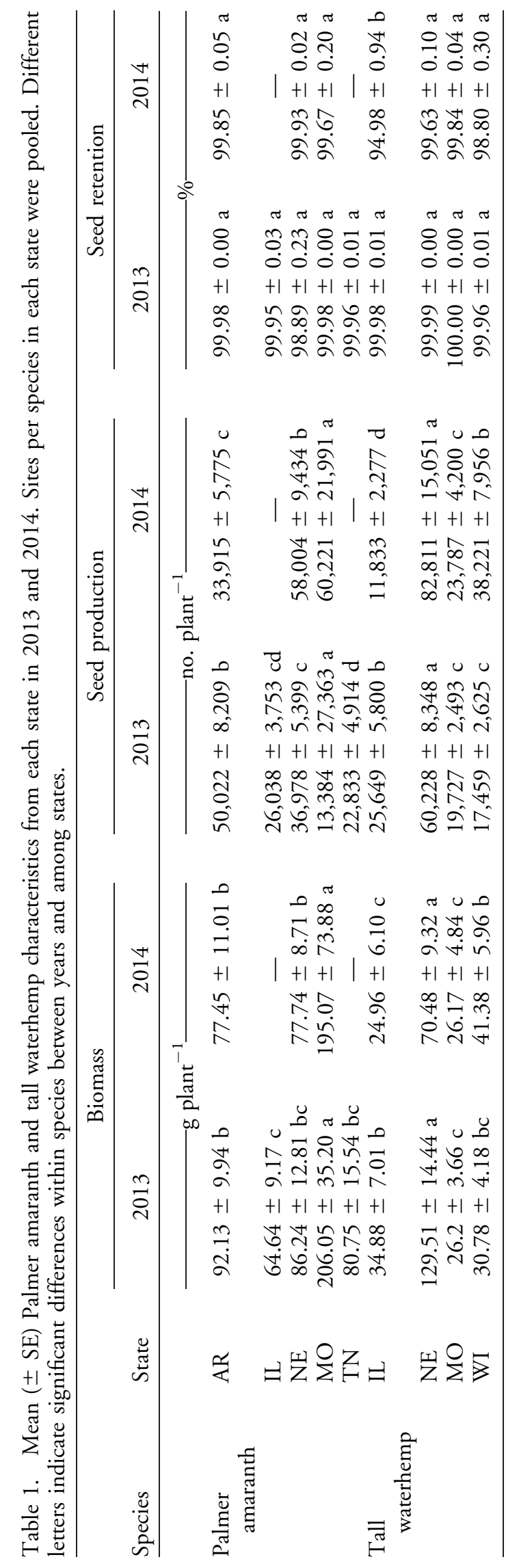

performed. Additionally, multiple linear regression analysis was performed to determine if a combination of variables affected seed retention.

\section{Results and Discussion}

Biomass (g) for Palmer amaranth plants, regardless of state or year (2012 to 2014), ranged from 7.69 to $1,143.3 \mathrm{~g}$ (mean of $64.64 \pm 9.17$ to $206.05 \pm$ 35.20). In comparison, tall waterhemp plant weights (2013 to 2014) had a range of 24.96 to $129.51 \mathrm{~g}$ (mean of $24.96 \pm 6.10$ to $129.51 \pm 14.44$ ). Palmer amaranth plants produced seeds ranging from 1,011 to 796,135 seeds per plant (mean $13,384 \pm 27,363$ to $60,221 \pm 21,991)$ across locations and years. Furthermore, tall waterhemp plants produced seeds ranging from 135 to 305,831 seeds per plant (mean $11,833 \pm 2,277$ to $82,811 \pm 15,051)$ across locations and years. Total plant seed production in this study was generally lower than values previously documented in the literature $\left(600,000\right.$ seeds plant $\left.^{-1}\right)$ for plants grown in the absence of soybean interference (Keeley et al. 1987; Norsworthy et al. 2012; Sellers et al. 2003). However, in some instances, especially for Palmer amaranth, plant seed production was close to values reported in previous studies (Dalley et al. 2004; Jha et al. 2008). Variation in plant seed production can result from weed control tactics, time of emergence, local and regional climatic differences, and soybean crop competition. Varying management practices by individual growers is known to alter the emergence of the weed species, which in turn can influence seed production potential (Norsworthy et al. 2012). Late-emerging plants are smaller and produce less seed per plant than earlier-emerging plants.

Seed retention was consistently very high across all regions. Percent seed retention of Palmer amaranth and tall waterhemp ranged from 94.98 to $100 \%$ and 98.89 to $99.98 \%$, respectively. Illinois was the only state that exhibited a significant difference in average seed retention from 2013 (99.9\%) to 2014 (94.9\%) for tall waterhemp (Table 1). The lower retention in 2014 in Illinois was likely a result of a 1- to 2-wk delay in collecting samples as compared to 2013. Even so, the values in this study are as high or higher than what has been reported in Australia for rigid ryegrass (Lolium rigidum Gaudin), wild radish (Raphanus raphanistrum L.), brome grass (Bromus spp.), and wild oat (Avena 

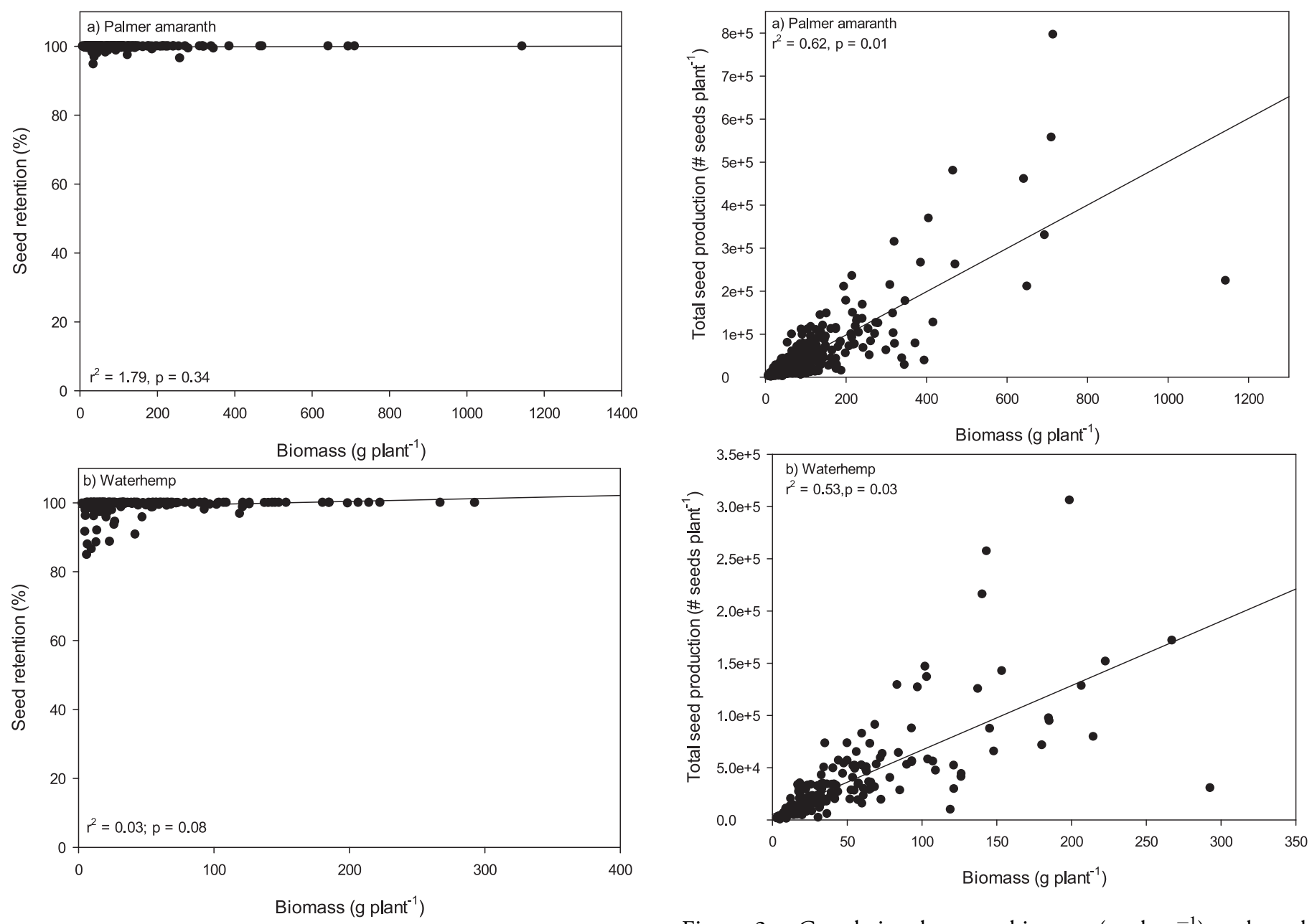

Figure 1. Correlation between seed retention (\%) and biomass (g plant ${ }^{-1}$ ) for (a) Palmer amaranth $(\mathrm{n}=228)$ and (b) tall waterhemp $(\mathrm{n}=193)$ in 2013 and 2014 .

fatua L.), which retained 85 , 99, 77, and $84 \%$ of seed until crop maturity, respectively (Walsh and Powles 2014). Similarly, perennial ryegrass (Lolium perenne L.) had a $96 \%$ seed retention in wheat (Triticum aestivum L.) fields (Blanco-Moreno et al. 2004). Tall waterhemp and Palmer amaranth seed retention in all of the remaining states that were studied varied by no more than $0.01 \%$ between years, which means that seed retention was stable and a high percentage was available for HWSC. Furthermore, biomass and percent seed retention were not correlated or significant (Figure 1), which indicates that regardless of plant size, and possibly time of emergence, seed retention remained high and close to maximum.

Aboveground biomass and total seed production was highly correlated for both species (Figure 2).

Figure 2. Correlation between biomass $\left(\mathrm{g} \mathrm{plant}^{-1}\right.$ ) and total seed production per plant for (a) Palmer amaranth in 2012 to $2014(\mathrm{n}=352)$ and (b) tall waterhemp in 2012 to $2013(\mathrm{n}=$ 193).

Regardless of species, the majority of smaller plants had low seed production, indicating that these plants were late-emerging cohorts (Zimdahl 2004), possibly after the final herbicide applications. Additionally, it was apparent that many of the larger Palmer amaranth and tall waterhemp plants occurred in areas having a low population or weaker soybean plants. A strong correlation between biomass production and seed production has been well established for many weeds (Harrison 1990; Norris 2007; Steckel and Sprague 2004b; Webster and Grey 2015).

Seedling emergence (data not shown), which was conducted as an exhaustive grow-out from the soil and seeds that were collected from underneath each plant, was not reflective of the other characteristics (i.e., biomass, seed production, seed retention) and 
appeared to be solely a function of the number of seeds per plant or percent seed retention. Differences among states and years were not significant $(\mathrm{P}<0.07)$. The differences that did occur could have been a result of specific weather events (i.e., rainfall, strong winds) in the areas where the samples were collected.

Palmer amaranth and tall waterhemp are two of the most prominent agriculture weeds in the United States today. In most cases, farmers will harvest soybean fields with some mature weeds present, most likely due to the continual evolution of resistance to various herbicide modes of action. Thus, replenishment of the soil seedbank is common. Understanding more about weed seed retention at crop harvest is imperative to developing and utilizing nonchemical management practices to control weed species at that point. Various HWSC tactics, such as chaff carts (Walsh et al. 2012), narrow-windrow burning (Walsh and Newman 2007), the Harrington Seed Destructor (Walsh et al. 2012), and a bale-direct system (Walsh and Powles 2007) can be used to prevent weed seeds from entering into the soil seedbank. Additionally, understanding the quantity of weed seed added to the soil seedbank and knowledge of weed seed retention is necessary to develop tactics that decrease additions to the soil seedbank. Furthermore, this knowledge aids our understanding of the consequences of not targeting weed seed production at crop harvest. However, more research is still needed on these mechanisms to fully understand how to reduce the amount of weed seeds that are being retained in the soil seedbank as well as the implication of delayed harvest on seed retention.

\section{Acknowledgments}

The authors would like to thank all of the graduate students and student workers for their help in collecting the data. We would also like to thank the United Soybean Board for funding.

\section{Literature Cited}

Bensch CN, Horak MJ, Peterson D (2003) Interference of redroot pigweed (Amaranthus retroflexus), Palmer amaranth (Palmer amaranth), and common waterhemp (A. rudis) in soybean. Weed Sci 51:37-43

Blanco-Moreno JM, Chamorro L, Masalles RM, Recasens J, Sans FX (2004) Spatial distribution of Lolium rigidum seedlings following seed dispersal by combine harvesters. Weed Res 44:375-387

Costea M, Weaver SE, Tardif FJ (2005) The biology of invasive alien plants in Canada. 3. Amaranthus tuberculatus (Moq.) Sauer var. rudis (Sauer) Costea \& Tardif. Can J Plant Sci 85:507-522

Dalley CD, Kells JJ, Renner KA (2004) Effect of glyphosate application timing and row spacing on weed growth in corn (Zea mays) and soybean (Glycine max). Weed Technol 18:177182

Davis AS, Schutte BJ, Hager AG, Young BG (2015) Palmer amarnath (Amaranthus palmeri) damage niche in Illinois soybean is seed-limited. Weed Sci 63:658-668

Dieleman A, Hamill AS, Fox GC, Swanton CJ (1996) Decision rules for postemergence control of pigweed (Amaranthus spp.) in soybean (Glycine max). Weed Sci 44:126-132

Dunan CM, Westra P, Schweizer EE, Lybecker DW, Moore FD (1995) The concept and application of early economic period threshold: the case of DCPA in onions (Allium cepa). Weed Sci 43:634-639

Gill, GS (1996) Management of herbicide resistant ryegrass in Western Australia - research and its adoption. Pages 542-545 in Shepherd RCH, ed. 11th Australian Weeds Conference. Melbourne, Victoria, Australia: Weed Science Society of Victoria

Harrison SK (1990) Interference and seed production by common lambsquarters (Chenopodium album) in soybeans (Glycine max). Weed Sci 49:224-229

Hartzler RG, Buhler DD, Stoltenberg DE (1999) Emergence characteristics of four annual weed species. Weed Sci 47:578584

Heap I (2014) The International Survey of Herbicide Resistant Weeds. http://www.weedscience.com. Accessed July 07, 2015

Horak MJ, Loughin TM (2000) Growth analysis of four Amaranthus species. Weed Sci 48:347-355

Jha P, Norsworthy JK, Bridges W, Riley MB (2008) Influence of glyphosate timing and row width on Palmer amaranth (Amaranthus palmeri) and pusley (Richardia spp.) demographics in glyphosate-resistant soybean. Weed Sci 56:408-415

Johnson WG (2000) Herbicide resistant corn-survey results from 1998 and 2000. Proc North Cent Weed Sci Soc 55:7071

Keeley PE, Carter CH, Thullen RJ (1987) Influence of planting date on growth of Palmer amaranth (Amaranthus palmeri). Weed Sci 35:199-204

Knezevic SZ, Weise SF, Swanton CJ (1994) Interference of redroot pigweed (Amaranthus retroflexus) in corn (Zea mays). Weed Sci 42:568-573

Nordby D, Hartzler B, Bradley K 2007. Biology and Management of Waterhemp. Purdue Extension Publication GWC-13. In The Glyphosate, Weeds, and Crop Series. West Lafayette, IN: Purdue Exension. $11 \mathrm{p}$

Norris RF (2007) Weed fecundity: current status and future needs. Crop Prot 26:182-188

Norsworthy JK, Griffith G, Griffin T, Bagavathiannan M, Gbur EE (2014) In-field movement of glyphosate-resistant Palmer amaranth (Amaranthus palmeri) and its impact on cotton lint yield: evidence supporting a zero-threshold strategy. Weed Sci 62:237-249 
Norsworthy JK, Smith KL, Steckel LE, Koger CH (2009) Weed seed contamination of cotton gin trash. Weed Technol 23:574-580

Norwsorthy JK, Ward SM, Shaw DR, Llewellyn RS, Nichols RL, Webster TM, Bradley KW, Frisvold G, Powles SB, Burgos NR, Witt WW, Barrett M (2012) Reducing the risks of herbicide resistance: best management practices and recommendations. Weed Sci 60:31-62

Sellers BA, Smeda RJ, Johnson WG, Kendig JA, Ellersieck MR (2003) Comparative growth of six Amaranthus species in Missouri. Weed Sci 51:329-333

Sosnoskie LM, Webster TM, MacRae AW, Grey TL, Culpepper AS (2012) Pollen-mediated dispersal of glyphosate-resistance in Palmer amaranth under field conditions. Weed Sci 60:366373

Steckel LE, Main CL, Ellis AT, Mueller TC (2008) Palmer amaranth (Amaranthus palmeri) in Tennessee has low level glyphosate resistance. Weed Technol 22:119-123

Steckel LE, Sprague CL (2004a) Common waterhemp (Amaranthus rudis) interference in corn. Weed Sci 52:359-364

Steckel LE, Sprague CL (2004b) Late-season common waterhemp (Amaranthus rudis) interference in narrow- and widerow soybean. Weed Technol 18:947-952

Steckel LE, Sprague CL, Stoller EW, Wax LM (2004) Temperature effects on germination on nine Amaranthus species. Weed Sci 52:217-221

Swanton CJ, Nkoa R, Blackshaw RE (2015) Experimental methods for crop-weed competition studies. Weed Sci 63:211

Swanton CJ, Weise SF (1991) Integrated weed management: the rationale and approach. Weed Technol 5:657-663
Trucco F, Tranel PJ (2011) Amaranthus. Pages 11-21 in Kole C, ed. Wild Crop Relatives: Genomic and Breeding Resources. Berlin: Springer-Verlag

Walsh MJ, Harrington RB, Powles SB (2012) Harrington seed destructor: a new nonchemical weed control tool for global grain crops. Crop Sci 52:1343-1347

Walsh MJ, Newman P (2007) Burning narrow windrows for weed seed destruction. Field Crops Res 104:24-40

Walsh MJ, Newman P, Powles SB (2013) Targeting weed seeds in-crop: a new weed control paradigm for global agriculture. Weed Technol 27:431-436

Walsh MJ, Powles SB (2007) Management strategies for herbicide-resistant weed populations in Australian dryland crop production systems. Weed Technol 21:332-338

Walsh MJ, Powles SB (2014) High seed retention at maturity of annual weeds infesting crop fields highlights the potential for harvest weed seed control. Weed Technol 28:486-493

Ward SM, Webster TM, Steckel LE (2013) Palmer amaranth (Amaranthus palmeri): a review. Weed Technol 27:12-27

Webster TM, Grey TL (2015) Glyphosate-resistant Palmer amaranth (Amaranthus palmeri) morphology, growth, and seed production in Georgia. Weed Sci 63:264-282

Zimdahl RL (2004) Weed-Crop Competition, 2nd edn. Oxford, UK: Blackwell Publishing. $220 \mathrm{p}$

Received August 18, 2015, and approved September 23, 2015.

Associate Editor for this paper: Prashant Jha, Montana State University. 